\title{
Analysis of the Effect of Loading on the Transformers Usage Time
}

\author{
Adi Syahputra Ritonga ${ }^{\bowtie 1}$, Muchlis Abdul Muthalib ${ }^{2}$, Muhammad Daud $^{2}$,Hamdi Akmal Lubis³ ${ }^{3}$ Biswas Babu \\ Pokhrel$^{4}$, Sudip Phuyal5, \& Umakant B. Gohatre ${ }^{6}$
}

${ }^{1}$ Renewable Energy Engineering Master's Program, Malikussaleh University, Bukit Indah, Lhokseumawe, 24351, Indonesia

${ }^{2}$ Department of Electrical Engineering, Malikussaleh University, Bukit Indah, Lhokseumawe, 24351, Indonesia

${ }^{3}$ Faculty of Civil Engineering, Geo-and Environmental Sciences, Karlsruhe Institute of Technology (KIT), Karlsruhe, Germany

${ }^{4}$ Mid-Western University, Nepal

${ }^{5}$ Kathmandu University, Nepal

${ }^{6}$ SIGCE, Navi Mumbai, Mumbai university, Maharashtra, India

adiritonga01@gmail.com; muchlis.abd@unimal.ac.id; mdaud@unimal.ac.id; hamdi.lubis@kit.edu; pokharelbabubiswas@gmail.com; sudip1@yahoo.com; umakantgohatre1@gmail.com

${ }^{\square}$ Corresponding Author: adiritonga01@gmail.com| Phone: +6285297395431

Received: September 8, $2021 \quad$ Revision: September 21, $2021 \quad$ Accepted: September 28, 2021
Abstract
The reliability and stability of the system in the operation of the electric power system is very important, in order to
provide comfort in service to consumers. The transformer is a very important component in the electric power system,
because it is used as a voltage adjuster for the load being served. This study discusses the effect of loading and
temperature on the life shrinkage of 36/60 MVA power transformers in block 3 and block 4 carried out at PT. PJB UBJ
O\&M PLTMG Arun Lhokseumawe, Aceh. From the calculation results after 4 years the transformer operates, if the
transformer is given a $100 \%$ load, the transformer will experience an age difference of 2.52 p.u/day so that it has a
remaining life for of 10 years. As for the transformer that is given a load of $90 \%$, the transformer will experience an
age difference of 1.44 p.u/day so that it has a remaining life to perform operations for another 18 years. Then for a
transformer that is given a load of $80 \%$, the transformer will experience an age difference of 0.67 p.u/day so that it
will have a remaining life to carry out the operation again for another 38 years. From the above calculation, the origin
of the temperature obtained for the ONAN type of cooler in block 3 is 0.71 p.u/day and in block 4 it is 0.70 p.u/day.
While the ONAF type of cooler in block 3 is 0.004 p.u/day and in block 4 it is 0.005 p.u/day. This is in accordance
with the regulation SPLN50/1982 regarding transformer life shrinkage.
Keywords: electric power system; transformer; loading effect;

\section{Introduction}

The rapid development of electricity demand at this time must be followed by optimization of electrical power system equipment so that electrical energy can continue to be distributed continuously and uninterruptedly to electricity consumers(Pandapotan \& Warman, 2016).One of the most important pieces of equipment in the distribution of electric power is the power transformer. The function of this power transformer is to transform the voltage according to the needs of the load (Sulasno, 2001).

The transformer is a very important component in the electric power system, because it is used as a voltage adjuster for the load being served. Therefore, the quality of the transformer must be maintained so that it can last a long time (Solikhudin, 2010).Many things affect the decline in age, such as the temperature of the transformer and the temperature around the transformer, the worst loading occurs at the peak of $100 \%$ with a relatively low average life expectancy. With the increase in the load factor and ambient temperature, the aging rate of the transformer increases and the life of the transformer decreases with the operation of the transformer(Andika et al., 2018).

PT. PJB UBJ O\&M PLMG Arun is a power plant with a capacity of $184 \mathrm{MW}$ and supplies electrical power in the city of lhokseumawe and its surroundings. Meanwhile, the increasing use of electrical power is increasing so that the effect of loading the power transformer is also a problem during the period of using the transformer (Sigit et al., 2011).

\section{Literature Review}

Transformer is an electrical equipment that is included in the classification of electric machines and serves to distribute electrical power from high voltage to low voltage or vice versa, with the same frequency(Petra, 2017). In operation, power transformers are generally grounded at the neutral point, according to the need for a safety or protection system(Situmorang, 2011). For example, a 150/70 kV transformer is earthed directly on the neutral side of 150 $\mathrm{kV}$, and a $70 / 20 \mathrm{kV}$ transformer is earthed with a resistance on the neutral side of $20 \mathrm{kV}$. The basic theory of the transformer is "If there is alternating electric current flowing through the iron core, the iron core will turn large and if the 
magnet is surrounded by windings then at both ends of the winding there will be voltage. around the magnet, so that an electromotive force (EMF) will arise(Bambang N \& others, 2020).

Transformer oil is one of the liquid insulating materials used as insulation and coolant in transformers. As part of the insulating material, oil must have the ability to withstand breakdown voltages, while as a coolant, transformer oil must be considered capable of handling the heat generated, so with these two capabilities, the oil is expected to be able to protect the transformer from interference (Putra \& Murdiya, 2017).

Table 1. Transformer cooling type (Efendi, 2018)

\begin{tabular}{|c|c|c|c|c|c|}
\hline \multirow{3}{*}{ No } & \multirow{3}{*}{ Cooling System Type } & \multicolumn{4}{|c|}{ Media } \\
\hline & & \multicolumn{2}{|c|}{ Inside the Transformer } & \multicolumn{2}{|c|}{ Outside the Transformer } \\
\hline & & Natural Circulation & Forced Circulation & Natural Circulation & Forced Circulation \\
\hline 1 & AN & - & - & Air & - \\
\hline 2 & $\mathrm{AF}$ & - & - & - & Air \\
\hline 3 & ONAN & Oil & - & Air & - \\
\hline 4 & ONAF & Oil & - & - & Air \\
\hline 5 & OFAN & - & Oil & Air & - \\
\hline 6 & OFAF & - & Oil & - & Air \\
\hline 7 & OFWF & - & Oil & - & Air \\
\hline 8 & ONAN/ ONAF & & Combinat & on3 and 4 & \\
\hline 9 & ONAN/ OFAN & & Combinat & on3 and 5 & \\
\hline 10 & ONAN/ OFAF & & Combinat & on3 and 6 & \\
\hline 11 & ONAN/ OFWF & & Combinat & on3 and 7 & \\
\hline
\end{tabular}

The IEC specifies a transformer life of 20 years or 7300 days, so the normal life loss is $0.0137 \%$ per day. Shrinkage due to hot temperatures can be seen in table 2.

Table 2. Transformer cooling type(Sulasno, 2001)

\begin{tabular}{cccccccccccc}
\hline $0^{\circ} \mathrm{C}$ & 80 & 86 & 92 & 98 & 104 & 110 & 116 & 122 & 128 & 134 & 140 \\
\hline$\Delta 1$ day & 0.125 & 0.25 & 0.5 & 1 & 2 & 4 & 8 & 16 & 32 & 64 & 128 \\
\hline
\end{tabular}

\section{Materials \&Methods}

This study discusses the effect of loading and environmental temperature on shrinkage of 36/60 MVA power transformers block 3 and block 4 conducted at PT. PJB UBJ O\&M PLTMG ArunLhokseumawe, Nangroe Aceh Darussalam.This research was conducted by direct observation to the field and the data obtained were in the form of observational data on transformers which became the object of research as well as observations of the temperature around the observation location. This study also uses quantitative data, namely data in the form of numbers such as transformer loading data for 24 hours.

For certain rated power conditions: Natural oil circulation Increase in average coil temperature (measured by resistance $)=60^{\circ} \mathrm{C}$. Top oil temperature rise $\left(\Delta \theta_{w o}\right)=55^{\circ} \mathrm{C}$. The increase in the average temperature of the oil $\left(\Delta \theta_{b}\right)=40^{\circ} \mathrm{C}$. The difference between the average temperature rises of the coil and the average temperature rise of the oil $\left(\Delta \theta_{w o}\right)=21^{\circ} \mathrm{C}$. (Source: PT PJB UBJ O\&M PLTMG Arun, 2019). 2001):

Hot spot temperature rise $\left(\left(\Delta \theta_{c r}\right)\right.$ is arranged as follows(Syahputri Marantika, 2016)(Siahaan, 2018)(Perera et al.,

$$
\Delta \theta_{c r}=\Delta \theta_{b}+1,1 \Delta \theta_{w o}
$$

a. Top oil temperature rise

$$
\Delta \theta_{b}=\Delta \theta_{b r}\left[\frac{1+d K^{2}}{1+d}\right]^{x}
$$

$$
\begin{aligned}
& \text { Information : } \mathrm{d} \quad=\text { high ratio } \\
& \mathrm{x}=\text { constant } \\
& \mathrm{x} \quad=0,9(\mathrm{ONAN} \text { and ONAF })^{*} \\
& \mathrm{x}=1,0(\mathrm{OFAF} \text { and } \mathrm{OFWF})^{*} \\
& \Delta \theta_{b r} \quad=\text { suhu } \\
& \mathrm{K}=\text { load factor (load supply/load rating) }
\end{aligned}
$$

b. Hot spot temperature rise

$$
\theta_{c}=\theta_{a}+\Delta \theta_{\text {on }}+\Delta \theta_{t d}
$$

$$
\text { Information: } \quad \begin{array}{ll}
\theta_{a} & =\text { ambient temperature } \\
\Delta \theta_{o n} & =\text { increase in top oil temperature } \\
\Delta \theta_{t d} & =\text { temperature difference between hot spots and top oil }
\end{array}
$$

$$
\Delta \theta_{c}=\Delta \theta_{b r}\left[\frac{1+d K^{2}}{1+d}\right]+\left(\Delta \theta_{c r}-\Delta \theta_{b r}\right) K^{2 y}
$$




Information: $\quad \begin{array}{ll}\Delta \theta_{c r} & =\text { hot spot temperature rise } \\ \mathrm{y} & =\text { constant } \\ \mathrm{y} & =0,8(\mathrm{ONAN} \text { and ONAF }) \\ \mathrm{y} & =0,9(\mathrm{OFAF} \text { and OFWF }) \\ \Delta \theta_{b r \mathrm{r}} & =\text { increase in top oil temperature }\end{array}$

c. Counting aging

$$
\int_{\mathrm{t} 1}^{\mathrm{t} 2} \mathrm{~V} d \mathrm{t}=\frac{\mathrm{h}}{3}\left\{\mathrm{~V}_{o}+\mathrm{V}_{n}+4\left(\mathrm{~V}_{\text {odd }}\right)+2\left(\mathrm{~V}_{\text {even }}\right)\right\}=\frac{\mathrm{h}}{3}\left\{2 \mathrm{~V}_{n}+4\left(\mathrm{~V}_{\text {odd }}\right)+2\left(\mathrm{~V}_{\text {even }}\right)\right\}(5)
$$

Characteristic curve $\mathrm{V}, \mathrm{V}_{0}=\mathrm{V}_{\mathrm{n}}$

$$
\text { Information: } \begin{aligned}
\mathrm{h} & =\text { constant }(1) \\
\mathrm{T} & =\text { time } \\
\mathrm{V}_{\text {odd }}, \mathrm{V}_{\text {even }} & =\text { relative thermal aging rate }
\end{aligned}
$$

\section{Results and Discussion}

\section{Calculations For Constant Load}

Calculations are carried out to obtain the effect of various kinds of loading on the power transformer. Then the magnitude of the load is made constant which can be seen in the following table.

Table 3. Types of Loading

\begin{tabular}{cc}
\hline No & Transformer Load \\
\hline 1 & 100 \\
2 & 90 \\
3 & 80 \\
\hline
\end{tabular}

After calculating using the existing equations, it can be seen the value of the life loss on the power transformer and the remaining operating life based on each loading percentage can be seen in Table 4below:

Table 4. Shrinkage and remaining life of transformers of various kinds

\begin{tabular}{cccc}
\hline No & Load & Loss of Age (p.u/day) & Age (Years) \\
\hline 1 & 100 & 2.52 & 10 \\
2 & 90 & 1.44 & 18 \\
3 & 80 & 0.67 & 38 \\
\hline
\end{tabular}

\section{Effect of Ambient Temperature}

Table 5. Effect of Ambient Temperature on Constant Load

\begin{tabular}{ccccc}
\hline \multirow{2}{*}{ No } & \multirow{2}{*}{ Suhu $\left({ }^{\circ} \mathrm{C}\right)$} & \multicolumn{3}{c}{ Life Loss (p.u/day) at Stable Load } \\
\cline { 3 - 5 } & 20 & $80 \%$ & $90 \%$ & $100 \%$ \\
\hline 1 & 21 & 0.26 & 0.57 & 1.00 \\
2 & 22 & 0.30 & 0.64 & 1.12 \\
3 & 23 & 0.33 & 0.72 & 1.26 \\
4 & 24 & 0.37 & 0.81 & 1.41 \\
5 & 25 & 0.42 & 0.91 & 1.59 \\
6 & 26 & 0.47 & 1.02 & 1.78 \\
7 & 27 & 0.53 & 1.15 & 2.00 \\
8 & 28 & 0.59 & 1.29 & 2.25 \\
9 & 29 & 0.66 & 1.45 & 2.52 \\
10 & 30 & 0.74 & 1.62 & 2.83 \\
11 & 31 & 0.84 & 1.82 & 3.18 \\
12 & 32 & 0.94 & 2.04 & 3.56 \\
13 & & 1.05 & 2.29 & 4.00 \\
\hline
\end{tabular}

The calculation results can be seen in table 5 above, the temperature change from the lowest to the highest is namely $20^{\circ} \mathrm{C}$ to $32^{\circ} \mathrm{C}$ makes the age loss at each load change. For loading of $80 \%$ the life shrinkage on the transformer is at 0.26 p.u/day to 1.05 p.u/day. And for loading of $90 \%$ the life shrinkage on the transformer is at 0.57 p.u/day to 2.29 p.u/day. While for loading of $100 \%$ the life shrinkage on the transformer is at 1.00 p.u/day to 4.00 p.u/day. From the results of the analysis, it can be explained that the difference in age loss for each load is the same because the transformer has a constant load. So based on the SPLN 50/1982 regulation regarding the life loss of the transformer in accordance with the calculation results obtained. 


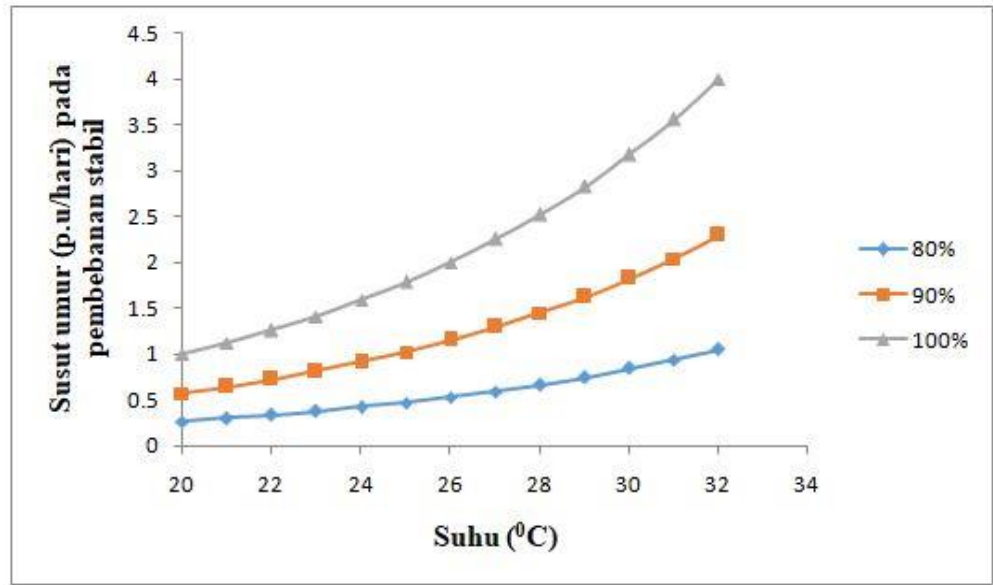

Figure 1. Effect of Ambient Temperature on Constant Load

Based on Figure 1.above, it is explained that the effect of ambient temperature greatly affects a constant load. It can be seen in Figure 4.1 that the greater the temperature given to the power transformer, the life loss obtained will be even greater by being given a high load, this can be proven at a high load, namely $100 \%$ of the resulting life loss is very large, which is $4 \mathrm{pu}$ / days given the high temperature of the transformer, which is $32^{\circ} \mathrm{C}$.

\section{Calculations for Power Transformer Loading}

The magnitude of the rated power of the power transformer at PT. PJB UBJ O\&M PLTMG ArunLhokseumawe, Nangroe Aceh Darussalam used is 32/60 MVA (ONAN/ONAF). The power transformer load for block 3 on 20 November 2019 at 19:00 is 34.88 MW 5.76 MVAR, while the power transformer load for block 4 on 20 November 2019 at 19:00 is $34.30 \mathrm{MV}$ 7, 78 MVARs.

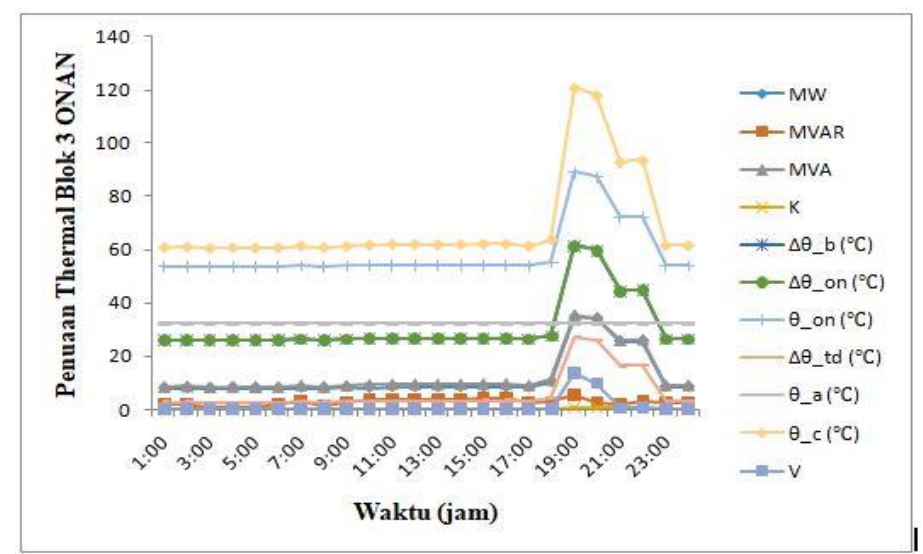

Figure 2. Calculation of thermal aging block 3 at each hour (ONAN)

Figure 2.above is the calculation of thermal aging in block 3 every hour on the ONAN cooling system. from the picture it can be explained that at 19.00 hours has the highest life loss in every analysis and calculation carried out this is because the value of MW and MVAR in the power transformer in the ONAN cooling system is higher at 19.00 so that the resulting life loss is greater at 19.00 is 13.97 years.

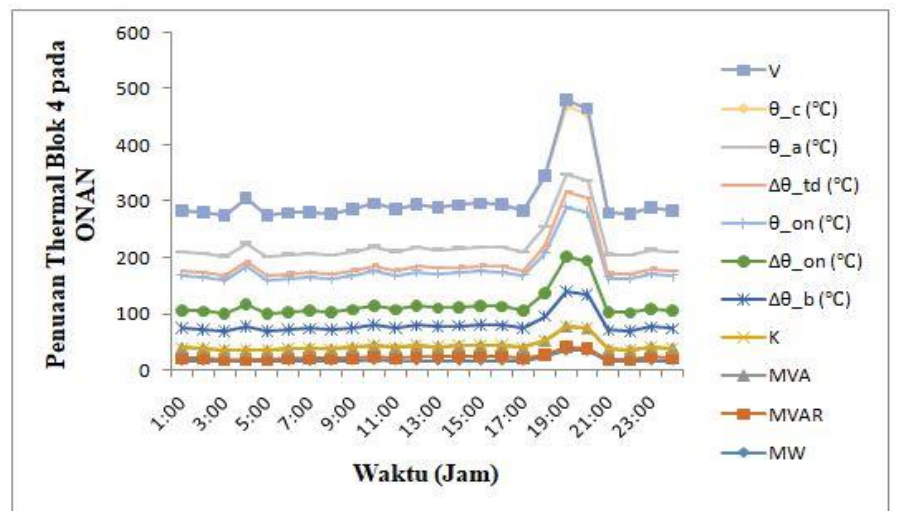

Figure 3. Calculation of thermal aging block 4 at each hour (ONAN) 
Figure 3.above is the calculation of thermal aging in block 4 each hour in the ONAN cooling system. From the picture above, it can be explained that at 19:00 hours it has the highest life loss, because the MW and MVAR values in the power transformer in the ONAN cooling system are higher at 19:00 so the resulting life loss is greater at 19 hours. :00 of 13.05 years.

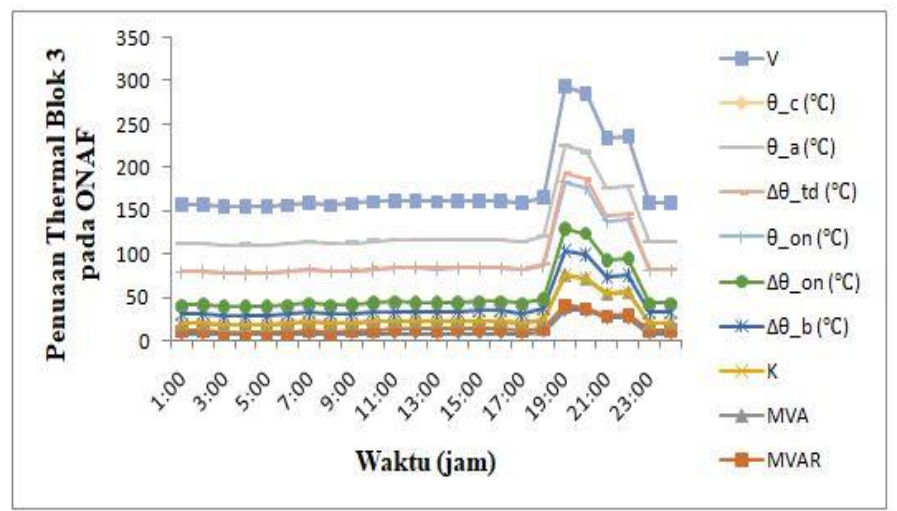

Figure 4. Calculation of thermal aging block 3 at each hour (ONAF)

Figure 4.above is the calculation of thermal aging in block 3 at each hour in the ONAF cooling system. From the picture above, it can be explained that at 19:00, the age loss is the highest in every analysis and calculation carried out. This is because the value of MW and MVAR in the power transformer in the ONAF cooling system is higher at 19:00 so that the resulting life loss is greater at 19:00 by 0.033 years.

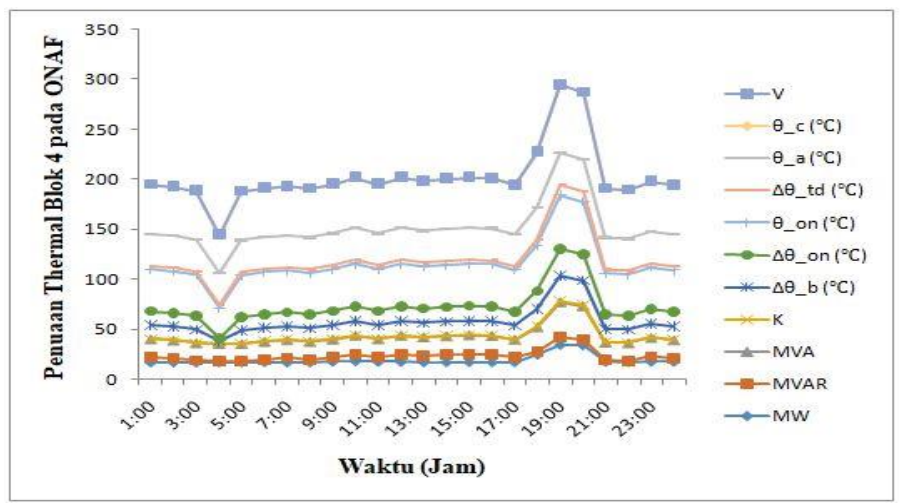

Figure 5. Calculation of thermal aging block 4 at each hour (ONAF)

Figure 5.above is the calculation of thermal aging in block 3 at each hour in the ONAF cooling system. From the figure, it can be explained that at 19:00, the age loss is the highest in every analysis and calculation carried out. This is because the value of MW and MVAR in the power transformer in the ONAF cooling system is higher at 19:00 so that the resulting life loss is greater at 19:00 by 0.032 years.

From the analysis, the age loss caused by ambient temperature was obtained for the ONAN type of cooler in block 3 of 0.71 p.u/day and in block 4 of 0.70 p.u/day. While the ONAF type of cooler in block 3 is 0.004 p.u/day and in block 4 it is $0.005 \mathrm{p} . \mathrm{u} /$ day.

\section{Conclusions}

The conclusions that the author can draw from the research that has been done based on the results of calculations and analyzes carried out are as follows:

1. The effect of temperature on the calculation of the age loss is every increase in temperature starting from the lowest temperature of $20^{\circ} \mathrm{C}$ to the highest temperature of $32^{\circ} \mathrm{C}$ in Indonesia, at each load of $80 \%, 90 \%$ and $100 \%$, a very rapid increase in age loss is obtained, namely for a load of $80 \%$ from the lowest 0.26 to the highest 1.05 $\mathrm{pu} /$ day and for the load $90 \%$ from the lowest 0.57 to the highest $2.29 \mathrm{pu}$ /day and for the load $100 \%$ from the lowest 1.00 to the highest $4.00 \mathrm{pu} /$ day.

2. From the calculation results at $80 \%, 90 \%$ and $100 \%$ constant loading, the age loss value is obtained, respectively, namely 0.67 p.u/day; 1.44 p.u/day and $2.52 \mathrm{p} . \mathrm{u} /$ day and for the remaining life of the power transformer, respectively, namely 38 years, 18 years and 10 years.

3. The transformer life loss value is based on loading data on November 20, 2019, namely the ONAN type cooling network in block 3 of $0.71 \mathrm{pu} /$ day and in block 4 of $0.70 \mathrm{pu} /$ day while on the ONAF type cooling network in block 3 of $0.004 \mathrm{pu} /$ day and in block 4 of $0.005 \mathrm{pu} /$ day. This is in accordance with the regulation SPLN50/1982 regarding transformer life shrinkage. 


\section{References}

Andika, D. A. Y., Agus Supardi, S. T., \& others. (2018). Effect of Loading on the Life of the Power Transformer at the $150 \mathrm{kV}$. Palur Substation. Muhammadiyah University of Surakarta.

Bambang N, A., \& others. (2020). Analysis of Transformer Costs Due to Total Power Loss Using the Annual Worth Method at the Wonogiri Hydroelectric Power Plant. Muhammadiyah University of Surakarta.

Efendi, S. R. I. M. (2018). Transformer Cooling System At PLTMG ARUN 184 MW. ETD Unsyiah.

Pandapotan, J., \& Warman, E. (2016). Study of the Effect of Loading on Power Transformer Life Loss. Jurnal Singuda Ensikom, 3(1).

Perera, K., Lucas, J. R., Kumarasinghe, K., Dias, R., Athukorala, U., \& Gunawardana, P. G. A. (2001). Estimation of optimum transformer capacity based on load curve. Trans. Inst. Elect. Eng. Sri Lanka, 3(1).

Petra, F. (2017). Overcurrent protection for 2000 KVA transformer, 3.3 KV/380-220 Volt voltage at PT Century Textile Indonesia.

Putra, R. K., \& Murdiya, F. (2017). Characteristics of Alternating Current Translucent Voltage in Castor Oil (Jatropha curcas) as an Alternative to Liquid Insulation.Riau University.

Siahaan, C. (2018). Power Transformer Aging Model Assessment According to IEC/IEEE Standards and Economic Value Determination by Annual Rate Method.

Sigit, P., Sukamdi, T., \& Karnoto, K. (2011). Analysis of the Effect of Loading on Power Transformer Life Loss. Department of Electrical Engineering, Faculty of Engineering Undip.

Situmorang, B. M. (2011). Analysis of Transformer Costs Due to Total Power Loss with the Annual Worth Method. University of Indonesia.

Solikhudin, M. (2010). Study of Interbus Interbus Transformer (IBT-1) 500/150 kV at GITET 500 kV Kembangan-West Jakarta. Faculty of Engineering, Postgraduate Program in Engineering, University of Indonesia. Jakarta.

Sulasno, I. (2001). TEngineering and Electric Power Distribution System. Volume I, Diponegoro University Publishing Agency, Semarang.

Syahputri Marantika, N. (2016). Calculation of Life Loss of 30 MVA Power Transformer Due to Loading on PT. Padang Cement. Padang State Polytechnic. 